DE LEGA LATA

Jurnal Ilmu Hukum

FAKULTAS HUKUM UMSU

\title{
KATA SEPAKAT DALAM PERJANJIAN DAN RELEVANSINYA SEBAGAI UPAYA PENCEGAHAN WANPRESTASI
}

\author{
Isdian Anggraeny, Sholahuddin Al-Fatih \\ Fakultas Hukum, Universitas Muhammadiyah Malang \\ Jl. Raya Tlogomas No. 246 Malang, Jawa Timur \\ Email: isdian@umm.ac.id, sholahuddin.alfath@gmail.com
}

\begin{abstract}
Abstrak
Secara yuridis-formal, tegas ditentukan, bahwa setiap perjanjian mempersyaratkan adanya kata sepakat para pihak. Meski demikian, implementasi piranti normatif itu tidak semudah bunyi tekstualnya. Dengan menggunakan metode analisis yuridis, tulisan dengan tema "Kata Sepakat Dalam Perjanjian dan Relevansinya Sebagai Upaya Pencegahan Wanprestasi”, mengangkat dua permasalahan menarik. Pertama, bagaimana relevansi kata sepakat dalam perjanjian sebagai upaya mencegah wanprestasi; Kedua, bagaimana format ideal pemenuhan kata sepakat dalam perjanjian. Temuan dalam penelitian ini memastikan, bahwa: Pertama, kata sepakat merupakan kata kunci dalam menjamin terlaksananya dan terpenuhinya janji-jani para pihak dalam perjanjian. Oleh karenanya, dalam perjanjian pada umunya, kata sepakat mempunyai relevansi untuk mencegah terjadinya wanprestasi. Kedua, secara ideal, dalam setiap perjanjian perlu dipastikan, bahwa para pihak benar-benar memahami apa yang disepakati baik secara formal maupun secara material (substansial).
\end{abstract}

\section{Kata Kunci: Kata Sepakat, Perjanjian, Wanprestasi.}

\section{Abstract}

In a juridical-formal, firmly determined, that each agreement requires the agreement of the parties. However, the implementation of normative tools is not as easy as the textual sounds. Through a juridical approach, writing with the theme "Agree to the Agreement and its Relevance as a Prevention of Default", raised two interesting problems. First, how is the relevance of the agreement in the agreement as an effort to prevent default; Second, what is the ideal format for agreement in an agreement. The findings in this study confirm, that: First, the agreement is the key word in ensuring the implementation and fulfillment of the promises of the parties to the agreement. Therefore, in agreement in general, the agreement has relevance to prevent defaults. Second, ideally, in every agreement it is necessary to ensure that the parties truly understand what has been agreed both formally and materially (substantially).

Keywords: Agree, Agreement, Default.

\section{PENDAHULUAN}

Perjanjian hakikatnya merupakan perbuatan hukum masyarakat untuk saling mengikatkan dirinya satu sama lain. Sebagai sarana saling mengikatkan diri satu sama lain, perjanjian mempersyaratkan terjadinya kata sepakat dari para pihak. Kata sepakat dalam perjanjian dapat dilihat sebagai prasyarat dasar. Secara yuridis, tanpa kata sepakat dari para pihak, dapat dipastikan tidak akan terjadi perbuatan saling mengikatkan diri itu. Mengikatkan diri satu sama lain sesungguhnya bermakna adanya kesadaran untuk saling mengakui hak dan kewajiban para pihak. Justru karena adanya kesadaran untuk saling mengakui hak dan kewajiban inilah para pihak mengikatkan dan kemudian menundukkan diri pada apa yang 
DE LEGA LATA

Jurnal Ilmu Hukum

FAKULTAS HUKUM UMSU
Kata Sepakat Dalam...(Isdian Anggraeny, Sholahuddin Al-Fatih)

Volume 5 Nomor 1, Januari - Juni 2020, 57-66 DOI: https://doi.org/10.30596/dll.v5i1.3446

disepakati. Karenanya, kata sepakat juga dapat dimaknai sebagai kesadaran untuk saling menjamin terpenuhinya hak dan kewajiban masing-masing pihak.

Kata sepakat dalam perjanian hakikatnya tidak bermakna formalitas. Kata sepakat mengandung makna yang jauh lebih esensial dari sekedar formalitas. Di dalam kata sepakat terkandung makna adanya kehendak dari masing-masing pihak untuk saling meyakinkan, saling menepati janji dan harapan masing-masing. Karena itu, dalam kata sepakat juga terkandung makna adanya kepastian hukum. Dalam konteks perjanjian, kepastian hukum hakikatnya merupakan jaminan, bahwa apa yang disepakati dalam perjanjian dapat terlaksana dan terpenuhi sesuai janji masing-masing pihak. Adanya jaminan ini akan memberikan manfaat dan keuntungan bagi para pihak. Dengan demikian, maka kata sepakat juga bermakna adanya jaminan untuk saling memberikan manfaat dan keuntungan bagi masing-masing pihak.

Kesadaran terhadap pentingnya memahami kata sepakat dalam perjanjian, dengan demikian menjadi tuntutan bagi siapapun yang akan melakukan perjanjian atau kesepakatan. Kesadaran ini akan berfungsi sebagai pengikat para pihak untuk menunaikan janji-janji yang telah disepakatinya. Dengan demikian kata sepakat dapat berfungsi untuk mencegah terjadinya ingkar janji atau wanprestasi. Kesadaran terhadap pentingnya kata sepakat dengan demikian menjadi "kata kunci" terlaksananya sebuah perjanjian. Meski juga tidak dapat dipungkiri, bahwa di dalam dunia praktek, ada indikasi, bahwa tidak semua perjanjian dilandaskan pada adanya kata sepakat. Tidak adanya kata sepakat dalam perjanjian tentu maknanya sangat luas. Dalam dunia praktek, tidak adanya kata sepakat dalam perjanjian misalnya dapat terjadi karena tidak bertemunya para pihak secara face to face di hadapan notaris. Tiadanya kata sepakat juga dapat bermakna tidak adanya pemahaman tentang apa yang disepakati. Karena itu, ada kebutuhan akademik yang cukup mendesak untuk dilakukan penelitian terhadap persoalan kata sepakat dalam perjanjian, khususnya sebagai upaya mencegah terjadinya ingkar janji (wanprestasi).

Mengingat keterbatasan ruang dan waktu penyajian, penelitian ini akan mencukupkan diri pada persoalan kata sepakat dalam perjanjian khususnya dalam kaitannya dengan wanprestasi. Penelitian ini akan diawali dengan mengidentifikasi dan menganalisis berbagai hal terkait prinsip hukum perjanjian. Pada area yang lebih khusus, penelitian ini juga akan mendiskusikan secara lebih detail tentang konsep kesepakatan, yang diawali dengan mencari konsep kesepakatan dalam perjanjian hingga pada akhirnya menemukan kesatuan prinsip hukum sebagai upaya mencegah wanprestasi. Untuk memudahkan kajian dan menistematisasikan uraian penyajian, penelitian ini akan mengajukan dua permasalahan pokok sebagai acuan pembahasan. Pertama, bagaimana relevansi kata sepakat dalam perjanjian sebagai upaya mencegah wanprestasi sesuai yang diatur dalam KUHPerdata; Kedua, bagaimana format ideal pemenuhan kata sepakat dalam perjanjian yang diatur dalam KUHPerdata.

\section{METODE PENELITIAN}

Penelitian ini merupakan penelitian normatif (legal research) dengan beberapa pendekatan sekaligus. Metode pendekatan yang digunakan dalam penelitian ini yaitu perundang-undangan (statute approach) dan pendekatan konsep (Conceptual approach) 


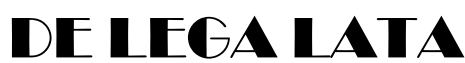

Jurnal Ilmu Hukum

FAKULTAS HUKUM UMSU
Kata Sepakat Dalam...(Isdian Anggraeny, Sholahuddin Al-Fatih)

Volume 5 Nomor 1, Januari - Juni 2020, 57-66 DOI: https://doi.org/10.30596/dll.v5i1.3446

(Ibrahim, 2000, h. 300-322). Pendekatan perundang-undangan (statute-approach), yaitu dengan menelaah peraturan perundang-undangan (Marzuki, 2007, h. 96) yang berkaitan dengan syarat sahnya perajanjian, terutama kata sepakat. Pendekatan konsep (conseptual approach), yaitu dengan menelaah dan memahami konsep-konsep (Ibrahim, 2007, h. 391) mengenai prinsip-prinsip perjanjian dan konsep kesepakatan dalam hukum perjanjian.

Penelitian ini juga akan mengeksplor nilai-nilai yang terdapat dalam hukum, oleh karenanya penelitian ini juga sekaligus merupakan penelitian filosofis (Yusriadi, 2009, h. 17). Sumber data yang dipergunakan dalam penelitian ini merupakan sumber data sekunder seperti buku-buku dan dokumen-dokumen ilmiah yang terkait dengan pokok bahasan. Penelitian ini tidak saja akan melihat hukum dalam tampilannya secara tekstual, tetapi akan melihat hukum dalam tampilannya sebagai ide, cita-cita, nilai, moral dan keadilan yang disebut sebagai konsep hukum yang idiologis, filosofis dan moralistis (Soemitro, 1989, h. 1). Sedangkan, teknik analisis bahan dilakukan dengan cara bahan-bahan hukum dikategorikan dan disusun secara sistematis. Teknik untuk menganalisis menggunakan sistem Interprestasi dalam teknis analisis bahan hukum, seperti penafsiran gramatikal, dan penafsiran sistematis.

\section{PEMBAHASAN DAN ANALISIS}

\section{Relevansi Kata Sepakat dalam Pejanjian Sebagai Upaya Mencegah Wanprestasi Sesuai yang Diatur dalam KUHPerdata}

Mengawali bahasan tentang relevansi kata sepakat dalam perjanjian sebagai upaya mencegah terjadinya wanprestasi, akan dipaparkan terlebih dahulu secara detail tentang perjanjian. Kajian tentang perjanian dalam konteks pembahasan permasalahan pertama didahulukan atas pertimbangan, bahwa kata sepakat sejatinya hanya merupakan salah satu syarat untuk sahnya perjanjian. Dengan demikian cukup beralasan kiranya pada bagian awal pembahasan ini dipaparkan terlebih dahulu hal-hal yang bersifat general. Pilihan atas model kajian ini juga dimaksudkan agar arah pembahasan dapat disajikan secara sistematis mulai dari hal-hal yang bersifat general menuju pada hal yang bersifat special. Melalui pembahasan yang demikian diharapkan pembahasan akan semakin mengerucut pada permasalahan yang menjadi pokok bahasan.

Sebagaimana pada bagian sebelumnya telah disinggung, bahwa perjanjian hakikatnya merupakan perbuatan hukum masyarakat untuk mengikatkan dirinya satu sama lain. Sebagai perbuatan hukum yang terjadi dalam kehidupan sehari-hari masyarakat, perjanjian mempunyai cakupan dan jangkauan yang demikian luas. Meski demikian, dalam perkembangannya, perjanjian lebih dikenali masyarakat dalam kaitannya dengan kehidupan berbisnis. oleh karenanya, persoalan tentang perjanjian sesungguhnya lebih dikenal dalam dunia bisnis. Berkaitan dengan realitas ini, Yohanes Sogar Simamora menyampaikan, bahwa perjanjian merupakan bagian yang melekat dari transaksi bisnis yang memiliki fungsi untuk menjamin seluruh harapan yang dibentuk dari janji-janji para pihak dapat terlaksana dan terpenuhi (Simamora, 2017, h. 25). Pandangan Simamora tentang perjanjian sesungguhnya menegaskan, bahwa perjanjian hakikatnya berfungsi sebagai sarana untuk memastikan, bahwa apa yang disepakati para pihak dapat dilaksanakan dan dapat dipenuhi. Dalam pandangan yang demikian sesungguhnya tersirat, bahwa perjanjian sesungguhnya merupakan sarana untuk menjamin 


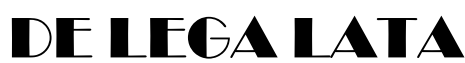

Jurnal Ilmu Hukum

FAKULTAS HUKUM UMSU
Kata Sepakat Dalam...(Isdian Anggraeny, Sholahuddin Al-Fatih)

Volume 5 Nomor 1, Januari - Juni 2020, 57-66 DOI: https://doi.org/10.30596/dll.v5i1.3446

kepastian hukum, dalam konteks ini adalah kepastian terwujudnya hak dan kewajiban para pihak sesuai yang disepakati.

Sementara itu secara yuridis formal sesuai dengan ketentuan Pasal 1313 Kitab UndangUndang Hukum Perdata (selanjutnya disebut dengan KUH Perdata) perjanjian dikonstruksi sebagai suatu perbuatan dengan mana satu orang atau lebih mengikatkan dirinya terhadap satu orang lain atau lebih. Secara tersurat, konsepsi ketentuan Pasal 1313 KUHPerdata menegaskan, bahwa perjanjian sejatinya merupakan perbuatan mengikatkan diri antara satu atau beberapa orang dengan seorang atau lebih. Senada dengan konsepsi yang dibangun KUHPerdata, Subekti memberikan batasan, bahwa perjanjian adalah suatu peristiwa dimana seorang berjanji kepada orang lain atau dimana dua orang itu saling berjanji untuk melaksanakan suatu hal (Subekti, 1987, h. 1). Dengan demikian nampak bahwa inti dari sebuah perjanjian adalah suatu kewajiban yang harus ditunaikan oleh salah satu/para pihak.

Melandaskan pada beberapa konsepsi tentang perjanjian sebagaimana paparan di atas, terbaca secara terang, bahwa perjanjian mempunyai beberapa fungsi sekaligus. Perjanjian di dalam kehidupan masyarakat memiliki beberapa fungsi, terutama untuk memberikan suatu kepastian tentang mengikatknya perjanjian antara para pihak. Lebih lanjut oleh Lukman Santoso AZ dalam bukunya telah membedakan fungsi perjanjian menjadi 2 macam yaitu fungsi yuridis dan fungsi ekonomis (AZ, 2016, h. 18). Fungsi yuridis perjanjian yaitu untuk memberikan kepastian hukum bagi para pihak. Sedangkan fungsi ekonomis perjanjian yaitu untuk merubah nilai penggunaan suatu sumber daya yang sebelmunya bernilai rendah menjadi nilai yang lebih tinggi. Melihat begitu pentingnya perjanjian maka seharusnya perjanjian menguntungkan bagi para pihak secara timbal balik. Pada titik ini, sangat dipahami jika perjanjian menjadi persoalan penting dalam kehidupan masyarakat modern sekarang ini. Mengingat kehadirannya tidak saja penting dalam konteks kepentingan hukum, tetapi juga penting dalam konteks kepentingan ekonomi. Karena itu menjadi wajar jika persoalan perjanjian berkembang demikian pesat, khususnya dalam ranah hukum privat.

Sebagai bagian dari hukum privat, hukum perjanjian saat ini sangat berkembang seiring dengan kebutuhan masyarakat. Berdasarkan pada asas kebebasan berkontrak dalam pasal 1338 KUH Perdata, para pihak dalam kontrak bebas untuk membuat perjanjian, apapun isi dan bagaimanapun bentuknya semua perjanjian yang dibuat secara sah berlaku bagi undang-undang bagi mereka yang membuatnya. Perjanjian yang merupakan undang-undang bagi para pihak maka dalam konteks pembuatan perjanjian (perjanjian yang dibuat secara tertulis maupun secara lisan) harus melibatkan kesadaran para pihak untuk memahami perjanjian sehingga dalam pra pembuatan kontrak hingga pasca pembuatan perjanjian dapat berjalan dengan baik dan melindungi masing-masing pihak. Selain itu, perjanjian yang dibuat juga harus memenuhi asas-asas di dalam hukum perjanjian lainnya, seperti: asas konsesualisme, asas kekuatan mengikat, dan asas keseimbangan (Budiono, 2014, h. 29-32). Akan tetapi, yang perlu kita ingat bahwa asas kebebasan berkontrak tersebut tetap tidak boleh melanggar syarat-syarat sahnya perjanjian dalam KUH Perdata.

Perjanjian akan menjadi sah dan memiliki kekuatan mengikat secara hukum bagi para pihak yang membuatnya apabila memenuhi syarat sah perjanjian. Syarat sahnya perjanjian diatur dalam pasal 1320 KUH Perdata sampai dengan pasal 1337 KUH Perdata. Berdasarkan 


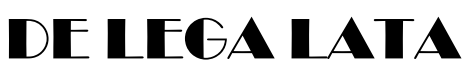

Jurnal Ilmu Hukum

FAKULTAS HUKUM UMSU
Kata Sepakat Dalam...(Isdian Anggraeny, Sholahuddin Al-Fatih)

Volume 5 Nomor 1, Januari - Juni 2020, 57-66 DOI: https://doi.org/10.30596/dll.v5i1.3446

Pasal 1320 KUH Perdata menentukan bahwa terdapat empat syarat sahnya perjanjian, yaitu: a. Sepakat untuk mengikatkan diri; b. Cakap untuk membuat suatu kontrak; c. Mengenai suatu hal tertentu; d. Suatu sebab yang halal. Jika keempat syarat tersebut dipenuhi oleh suatu perjanjian maka terhadap perjanjian tersebut berlaku ketentuan: 1) Perjanjian tersebut berlaku sebagai undang-undang bagi para pihak; 2) Perjanjian tidak dapat ditarik kembali secara sepihak tanpa kesepakatan bersama; 3) Pelaksanaan kontrak harus dilakukan dengan itikad baik (AZ, 2016, h. 23).

Namun, seiring perkembangan dunia bisnis dan kebutuhan masyarakat, seringkali timbul permasalahan dari perikatan yang dilakukan masing-masing individu, terutama yang perikatan yang timbul dari perjanjian. Seringkali dijumpai suatu hubungan perdata yang dimulai dari suatu perjanjian kedua belah pihak kemudian dalam pelaksanaannya menjadi perkara pidana, meskipun awalnya murni merupakan hubungan bisnis yang dilandasi itikad baik. Permasalahan yang seringkali berujung pada perkara pidana dan seringkali terjadi di masyarakat yaitu: praktik penyalahgunaan uang yang dipinjam namun tidak sesuai dengan peruntukannya, suatu kewajiban dalam perjanjian yang tidak berhasil dipenuhi namun uang pembayaran tidak dikembalikan, pemberian cek kosong yang sejak awal diketahui tidak ada dananya, dan bahkan salah satu pihak mengakui bahwa penandatangan dilakukan secara tidak sah meskipun diakui bahwa tanda tangan tersebut adalah sah miliknya.

Berdasarkan uraian kasus-kasus tersebut di atas, perkara pidana yang diawali dengan perjanjian bisnis, selalu berawal dari niat jahat dan itikad tidak baik dari si pelaku. Itikad baik tercermin dari sebelum sampai pada pelaksanaan perjanjian. Itikad baik ini harus dimulai dengan pemenuhan salah satu syarat sah perjanjian pada Pasal 1320 ayat (1) KUHPerdata yang mengharuskan adanya kesepakatan Para Pihak. Kesepakatan berarti ada persesuaian kehendak yang bebas antara para pihak mengenai hal-hal pokok yang diinginkan dalam perjanjian. William T. Major menyatakan bahwa terdapat beberapa elemen yang mendasari adanya suatu perjanjian sederhana. Elemen-elemen tersebut yaitu kesepakatan, niat, dan konsiderasi (janji/manfaat timbal balik) (Major, 2018, h. 15). Memenuhi elemen-elemen tersebut tentunya semua pihak harus telah mencapai kesepakatan atau dianggap telah mencapai kesepakatan. Kesepakatan tersebut tentunya didasari dengan adanya niat yang dimiliki oleh semua pihak untuk membuat perikatan hukum sehingga pada akhirnya semua pihak mendapatkan sejumlah manfaat dari janji/manfaat timbal balik berdasarkan butir-butir kesepakatan. Oleh karena itu, jika di dalam suatu perjanjian/transaksi tidak memenuhi salah satu elemen tersebut maka dapat dikatakan bahwa perjanjian itu tidak ada.

Persesuaian kehendak (dalam hal ini kesepakatan) ini dapat dilihat dalam pernyataan para pihak, karena kehendak tidak dapat diketahui oleh orang lain/tidak dapat dilihat oleh orang lain. Pernyataan kesepakatan dapat dilakukan secara tegas maupun secara diam-diam (Major, 2018, h. 19). Suatu perjanjian hanya mungkin terjadi atas suatu kesepakatan atas persetujuan para pihak. Eggens dalam Ibrahim dalam Artikel Ery Agus Prioyono menyatakan asas konsensualisme merupakan puncak peningkatan manusia yang tersirat dalam pepatah: een man eem man, een word een word. Eggens melanjutkan bahwa ungkapan orang harus dapat dipegang ucapannya merupakan tuntutan kesusilaan (Priyono, 2018, h. 22). 


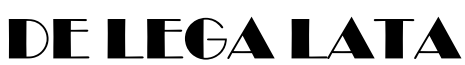

Jurnal Ilmu Hukum

FAKULTAS HUKUM UMSU
Kata Sepakat Dalam...(Isdian Anggraeny, Sholahuddin Al-Fatih)

Volume 5 Nomor 1, Januari - Juni 2020, 57-66 DOI: https://doi.org/10.30596/dll.v5i1.3446

Selanjutnya, Herlin Budiono menyatakan bahwa dalam menyusun suatu perjanjian sebaiknya bertolak dari sikap yang dikenal dengan istilah win-win attitude, suatu sikap yang dilandasi dengan itikad baik (Budiono, 2013, h. 244). Sebagai upaya pemenuhan sikap tersebut maka kesepakatan ini tentunya harus pula berdasarkan pada ketentuan Pasal $1321 \mathrm{KUH}$ Perdata. Pasal 1321 KUH Perdata mengatur bahwa kesepakatan yang sah adalah kesepakatan yang bebas dari kekhilafan, paksaan, dan penipuan. Hal ini dijelaskan pula oleh J. Satrio bahwa Sepakat yang benar pasti sepakat yang tidak tersesat, tidak terpaksa, tidak tertipu, dan tidak telah diberikan karena adanya penyalahgunaan keadaan (Satrio, 2019, h. 1). Dengan demikian perjanjian yang dimulai dengan kata sepakat dari para pihak dapat terlaksana dengan baik dan kepentingan masing-masing pihak terlindungi. Dalam hal ini, antara para pihak harus mempunyai kemauan yang bebas (sukarela) untuk mengikatkan diri, di mana kesepakatan itu dapat dinyatakan secara tegas maupun diam-diam. Bebas di sini artinya adalah bebas dari kekhilafan (dwaling, mistake), paksaan (dwang, dures), dan penipuan (bedrog, fraud).

Selain itu, selain pemenuhan Pasal 1321 KUH Perdata, kesepakatan harus dianalisis lebih lanjut berdasarkan teori-teori yang digunakan untuk menentukan saat terjadinya kesepakatan para pihak, yaitu: teori kehendak, teori pernyataan, dan teori kepercayaan (Budiono, 2010, h. 76). Teori kehendak menyatakan bahwa perjanjian ditentukan oleh faktor kehendak para pihak saja meskipun terkadang kehendak tersebut tidak sesuai dengan pernyataan pihak tersebut. Teori ini jelas memiliki kelemahan karena secara hukum formil seseorang harus mempercayai apa yang dinyatakan oleh orang lain sebelum dibuktikan sebaliknya. Berbeda dengan teori pernyataan, teori ini menyatakan bahwa kehendak para pihak harus dinyatakan dan pernyataan itulah yang mengikat para pihak. Namun, teori ini pun memiliki kelemahan mana kala apa yang dinyatakan oleh para pihak tidak sesuai dengan kehendak sehingga pada akhirnya menimbulkan kerugian. Misalnya, para pihak sepakat menjual barang dengan harga Rp. 10.000.000,00 (sepuluh juta rupiah), namun yang tertulis adalah Rp. 10.000,00 (sepuluh ribu rupiah). Untuk menyempurnakan teori-teori sebelumnya maka muncul teori kepercayaan yang menjelaskan bahwa pernyataan akan menjadi perjanjian apabila pernyataan tersebut menurut hukum kebiasaan menimbulkan kepercayaan bahwa hal yang dinyatakan adalah hal yang memang benar dikehendaki. Berdasarkan uraian teori ini, maka seharusnya kesepakatan itu terjadi pada saat adanya kehendak para pihak yang dinyatakan sehingga pihak lawan memahami dan menerima kehendak tersebut. Selain itu, pihak lawan juga harus memahami dan menerima kehendak tersebut dengan memperhatikan prinsip kehatiahatian dengan berdasarkan hukum kebiasaan yang ada di dalam masyarakat.

Berdasarkan pada analisis singkat di atas, maka para pihak pada saat melakukan persesuaian kehendak untuk mencapai kesepakatan yang sah secara hukum dan melindungi kepentingan masing-masing individu seharusnya memperhatikan beberapa faktor, yaitu penawaran kehendak kepada pihak lain, penyataan kehendak secara tegas, penerimaan kehendak dari orang lain, pernyataan penerimaan kehendak dari orang lain, penerapan prinsip kehati-hatian dengan berlandaskan itikad baik, dan penerapan Pasal 1321 KUH Perdata. Pada akhirnya, kesepakatan yang timbul adalah kesepakatan yang tidak tersesat, tidak terpaksa, tidak tertipu, dan tidak telah diberikan karena adanya penyalahgunaan keadaan. Selain itu, perjanjian yang lahir dari kesepakatan tersebut dapat terlaksana dengan baik dan melindungi kedua belah 
DE LEGA LATA

Jurnal Ilmu Hukum

FAKULTAS HUKUM UMSU
Kata Sepakat Dalam...(Isdian Anggraeny, Sholahuddin Al-Fatih)

Volume 5 Nomor 1, Januari - Juni 2020, 57-66

DOI: https://doi.org/10.30596/dll.v5i1.3446

pihak/para pihak. Dengan demikian tersimpul, bahwa kata sepakat dengan segala pengertiannya mempunyai relevansi terhadap upaya untuk mencegah terjadinya wanprestasi.

\section{Format Ideal Pemenuhan Kata Sepakat Dalam Perjanjian Sesuai yang Diatur dalam KUHPerdata}

Kata sepakat mengandung makna bahwa keinginan para pihak untuk saling mengikatkan diri dan keinginan ini menimbulkan kepercayaan bahwa perjanjian itu akan dipenuhi oleh para pihak (Priyono, 2018, h. 22). Kesepakatan juga merupakan faktor esensial yang menjiwai terbentuknya kontrak/perjanjian yang pada umumnya diungkapkan dengan kata setuju yang disertai dengan pembubuhan tanda tangan sebagai bukti persetujuan atas segala yang tercantum di dalam perjanjian (Sari, 2017, h. 82-83). Begitu pentingnya unsur kesepakatan dalam perjanjian untuk dipenuhi secara benar maka diperlukan suatu format ideal yang harus dipenuhi.

Kesepakatan dapat dibuat dalam suatu bentuk tertentu, yaitu: secara tertulis, secara lisan, disimpulkan secara logis berdasarkan tindakan masing-masing pihak dan situasi atau keadaan lingkungan kasus tersebut, atau gabungan dari berbagai cara tersebut (Major, 2018, h. 16). Sisi lain, Sudikono Mertokusumo dalam Jurnal Novi Ratna Sari menyatakan bahwa terdapat lima cara terjadinya persesuian pernyataan kehendak, yaitu dengan (Sari, 2017, h. 83):
a. Bahasa yang sempurna dan tertulis;
b. Bahasa yang sempurna secara lisan;
c. Bahasa yang tidak sempurna asal diterima oleh pihak lawan;
d. Bahasa isyarat kausal dapat diterima oleh pihak lawannya;
e. Diam atau membisu, tetapi asal dipahami atau diterima oleh Pihak Lawan.

Berdasarkan uraian tersebut, perjanjian dapat dibuat secara lisan maupun tertulis. Kedua cara tersebut tetap menjadikan perjanjian memiliki kekuatan mengikat para pihak dan tetap menimbulkan hak dan kewajiban dari para pihak yang bersepakat. Namun, hal ini perlu diperhatikan ketika dikaitkan dengan kemudahan dalam perihal pembuktian, sebagaimana diatur di dalam Pasal 1866 KUH Perdata. Alat pembuktian meliputi alat bukti secara tertulis, Alat bukti saksi, persangkaan, pengakuan, dan sumpah. Jika perjanjian dilakukan secara tertulis maka pembuktian mudah dilakukan, meskipun hukum meberikan alternatif pembuktian lain jika tidak ada bukti secara tertulis. Hasanuddin Rahmat menyatakan bahwa perumusan perjanjian sebaiknya dilakukan dalam bentuk tertulis dengan beberapa alasan (Rahmat, 2000, h. 2):

a. Perjanjian tertulis merupakan alat untuk menunjukann apakah perjanjian tersebut telah memenuhi syarat sah perjanjian atau belum;

b. Perjanjian tertulis dapat dijadikan alat untuk saling memantau para pihak apakah telah melaksanakan prestasinya atau belum atau bahkan telah wanprestasi;

c. Perjanjian tertulis sengaja dibuat untuk dijadikan alat bukti bagi pihak yang dirugikan untuk mengajukan ganti rugi kepada pihak lainnya.

Para pihak yang telah mencapai kata sepakat dapat menyatakan kesepakatan tersebut di dalam perjanjian secara tertulis. Selain itu, dengan memperhatikan analisis Penulis sebelumnya yaitu faktor-faktor yang harus diperhatikan dalam persesuaian kehendak untuk mencapai 
DE LEGA LATA

Jurnal Ilmu Hukum

FAKULTAS HUKUM UMSU
Kata Sepakat Dalam...(Isdian Anggraeny, Sholahuddin Al-Fatih)

Volume 5 Nomor 1, Januari - Juni 2020, 57-66

DOI: https://doi.org/10.30596/dll.v5i1.3446

kesepakatan yang sah secara hukum dan melindungi kepentingan masing-masing individu, maka disini Penulis menguraikan beberapa syarat-syarat yang harus dipenuhi para pihak dalam kesepakatan. Syarat tersebut dibedakan menajdi dua macam, yaitu syarat formal dan syarat meterial. Syarat formal pemenuhan kata sepakat meliputi:

a. Identitas para pihak dalam membuat perjanjian;

b. Kewenangan para pihak dalam membuat perjanjian;

c. Kecakapan para pihak sudah sesuai hukum atau belum;

d. Identitas obyek yang akan diperjanjikan;

e. Kehalalan obyek yang akan diperjanjikan.

f. Waktu dan tempat dimana para pihak melakukan kesepakatan; dan

g. Terdapat pembuktian atas kesepakatan yang dibuat para pihak sebagai alat bukti dalam penyelesaian sengketa.

Sedangkan syarat material pemenuhan kata sepakat dalam perjanjian, yaitu:

a. Kejelasan para pihak menyampaikan kehendak masing-masing;

b. Kesesuaian kehendak para pihak dengan aturan hukum yang berlaku;

c. Kesepakatan tidak tersesat, tidak terpaksa, tidak tertipu, dan tidak telah diberikan karena adanya penyalahgunaan keadaan;

d. Penerimaan dan kepercayaan pihak lain dalam perjanjian dalam persesuaian kehendak (kesepakatan);

e. Pernyataan secara tegas dari para pihak untuk bersepakat terhadap segala isi kesepakatan.

Pemenuhan syarat-syarat tersebut di atas selanjutnya direalisasikan dalam bentuk perjanjian sebagai wujud pernyataan atas kehendak masing-masing pihak dengan memperhatikan rancangan garis besar perjanjian dan dasar hukum atas segala perbuatan hukum yang akan dilakukan.

\section{KESIMPULAN}

Berdasarkan pembahasan tersebut diatas, dapat disimpulkan bahwa: Pertama, Kata sepakat dalam perjanjian sebagai upaya mencegah wanprestasi secara yuridis sangat relevan. Sebab, kesepakatan yang timbul adalah kesepakatan yang tidak tersesat, tidak terpaksa, tidak tertipu, dan tidak telah diberikan karena adanya penyalahgunaan keadaan. Selain itu, perjanjian yang lahir dari kesepakatan tersebut dapat terlaksana dengan baik dan melindungi kedua belah pihak/para pihak; Kedua, Format ideal pemenuhan kata sepakat dalam perjanjian harus memenuhi syarat formal (identitas para pihak dalam membuat perjanjian; kewenangan para pihak dalam membuat perjanjian; kecakapan para pihak sudah sesuai hukum atau belum; identitas obyek yang akan diperjanjikan;k ehalalan obyek yang akan diperjanjikan; waktu dan tempat dimana para pihak melakukan kesepakatan; dan terdapat pembuktian atas kesepakatan yang dibuat para pihak sebagai alat bukti dalam penyelesaian sengketa) dan syarat meterial (kejelasan para pihak menyampaikan kehendak masing-masing; kesesuaian kehendak para pihak dengan aturan hukum yang berlaku; kesepakatan tidak tersesat, tidak terpaksa, tidak tertipu, dan tidak telah diberikan karena adanya penyalahgunaan keadaan; penerimaan dan 
DE IFGA LATA

Jurnal Ilmu Hukum

FAKULTAS HUKUM UMSU

kepercayaan pihak lain dalam perjanjian dalam persesuaian kehendak (kesepakatan); dan pernyataan secara tegas dari para pihak untuk bersepakat terhadap segala isi kesepakatan).

\section{SARAN}

Berdasarkan hasil kesimpulan tersebut diatas, penulis ingin memberikan beberapa masukan atau saran, diantaranya: Pertama, Seyogyanya perlu dilakukan sosialisasi oleh stakeholders terkait pentingnya kata sepakat dalam perjanjian untuk mencegah terjadinya wanprestasi dalam segala bentuk atau aktifitas perikatan; Kedua, Seyogyanya stakeholders terkait memahami pentingnya penggunaan kata sepakat dalam perjanjian beserta pemenuhan terhadap syarat formil dan materilnya, upaya tersebut perlu ditindaklanjuti oleh pemerintah selaku pembuat undang-undang, dengan menuangkan regulasi dalam bentuk surat edaran atau sejenisnya. 
Jurnal Ilmu Hukum

FAKULTAS HUKUM UMSU
Kata Sepakat Dalam...(Isdian Anggraeny, Sholahuddin Al-Fatih)

Volume 5 Nomor 1, Januari - Juni 2020, 57-66 DOI: https://doi.org/10.30596/dll.v5i1.3446

\section{DAFTAR PUSTAKA}

Agus Priyono, Ery. (2018). Aspek Keadilan dalam Kontrak Bisnis di Indonesia. Jurnal Law Reform, Volume 14, Nomor 1

Budiono, Herlien. (2014). Ajaran Umum Hukum Perjanjian dan Penerapannya di Bidang Kenotariatan. Bandung: PT. Citra Aditya Bakti.

Budiono. Herlien. (2013). Kumpulan tulisan Hukum Perdata di Bidang Kenotariatan. Bandung: PT. Citra aditya Bakti

Hanitijo Soemitro, Ronny. (1989). Perspektif Sosial dalam Pemahaman Masalah-Masalah Hukum. Semarang: CV. Agung

Ibrahim, Johnny. (2005). Teori dan Metodologi Penelitian Hukum Normatif. Malang: Bayumedia

Mahmud Marzuki, Peter. (2007). Penelitian Hukum. Jakarta: Kencana

Rahmat, Hasanudiin. (2000). Legal Drafting. Bandung: Citra Adutya Bakti

Ratna Sari, Novi. (2017). Komparisi Syarat Sahnya Perjanjian menurut Kitab Undang-Undang Hukum Perdata dan Hukum Islam. Jurnal Repertorium Volume IV Nomor 2

Santoso AZ, Lukman. (2016). Hukum Perikatan" Teori Hukum dan Teknis Pembuatan Kontrak, Kerjasama, dan Bisnis. Malang: Setara Press

Satrio, J. (2019). Sepakat dan Permasalahannya: Perjanjian dengan Cacat dalam Kehendak, diakses dari https://www.hukumonline.com/berita/baca/lt5a4db425c9b56/sepakat-danpermasalahannya--lahirnya-perjanjian, pada tanggal 8 Agustus 2019 pukul 09:38 WIB

Sogar Simamora, Yohanes. (2017). Hukum Kontrak: Prinsip-prinsip Hukum Kontrak Pengadaan Barang dan jasa Pemerintah di Indonesia. Surabaya: LaksBang Pressindo.

Subekti, R. (1987). Hukum Perjanjian. Jakarta: Intermasa.

T. Major. William. (2018). Hukum Kontrak. Bandung: Nuansa Cendekia

Yusriadi. (2009). Tebaran Pemikiran Kritis Hukum dan Masyarakat. Malang: Surya Pena Gemilang. 